\title{
Enzymatic activity, microbial biomass, and organic carbon of Entisols from Brazilian tropical dry forest and annual and perennial crops
}

\author{
Krystal A. Notaro ${ }^{1}$, Erika V. de Medeiros ${ }^{1 *}$, Gustavo P. Duda², Keila A. Moreira ${ }^{1}$, Jamilly A. de Barros ${ }^{1}$, \\ Uemesson J. dos Santos², José Romualdo de S. Lima², and Wendson da S. Moraes ${ }^{1}$ \\ ${ }^{1}$ Universidade Federal Rural de Pernambuco, Laboratório de Enzimologia e Microbiologia Ambiental, Av. Bom Pastor, 55292- \\ 270, Garanhuns/PE, 55292-270, Brasil. .Corresponding author (evmbio@gmail.com). \\ ${ }^{2}$ Universidade Federal Rural de Pernambuco, Laboratório de Química Ambiental, Garanhuns 55292-270, Brasil.
}

Received: 22 August 2017; Accepted: 28 November 2017; doi:10.4067/S0718-58392018000100068

\begin{abstract}
The conversion of native forests into intensive agricultural cropping affects soil quality and ecosystem functionality in tropical dry areas. Although many indicators have been used to assess soil quality, the most sensitive indicators are biochemical attributes. Absolute enzymatic activity (fluorescein diacetate hydrolysis, dehydrogenase, $\beta$-glucosidase, urease, arylsulfatase, and acid and alkaline phosphatases), soil organic C (SOC), microbial biomass C (MBC), and specific enzymes per unit of SOC and MBC were measured in forests and perennial (tomato, pangola grass, cotton passion fruit, and cashew nuts) and annual (bean, cabbage, pigeon pea, and fennel) crops. The changes in soils covered with perennial crops differed from those covered with annual crops as regards biochemical soil attributes. The multivariate analysis grouped the Entisols covered with annual crops far from the forest soils, which indicated that intensive management results in drastic changes in the biochemical quality of Entisols in tropical dry areas. The absolute $\beta$-glucosidase activity varied from 18.3 to $100.6 \mu \mathrm{g} p$-nitrophenol $\mathrm{g}^{-1} \mathrm{soil} \mathrm{h}^{-1}$. The tomato areas showed higher dehydrogenase activity with a value of $181.5 \mu \mathrm{L} \mathrm{H} \mathrm{g}^{-1}$ soil. The absolute $\beta$-glucosidase, arylsulfatase, and alkaline phosphatase activity and the specific fluorescein diacetate hydrolysis/SOC, $\beta$-glucosidase/SOC, arylsulfatase/SOC, acid phosphatase/SOC, $\beta$-glucosidase/MBC, and acid phosphatase/MBC can be used as quality indicators of Entisols cultivated with perennial and annual crops. In addition, pasture soil could have a similar biochemical quality as forest soils in tropical dry areas.
\end{abstract}

Key words: Cropping systems, Entisols, soil organic carbon, specific enzyme activity per unit of soil organic carbon.

\section{INTRODUCTION}

Forests have been converted into agricultural areas, which can result in productive capacity losses, C emissions, and biodiversity losses, mainly in tropical dry areas that have most severely suffered anthropic uses (Quesada et al., 2009). This problem is attracting the attention of producers and has resulted in a search for tools aimed at monitoring agricultural soil quality (Pandey et al., 2014). This quality depends on a large number of chemical, biological, physical, microbiological, and biochemical indicators and it may be affected by soil use (Wang et al., 2012).

Thus, soil enzyme activity may respond more quickly to changes in soil systems (Acosta-Martínez et al., 2008; Medeiros et al., 2017) than other soil variables, and it is capable of reflecting ecosystem functions. Biochemical attributes are used extensively in the literature to assess quality in different land uses compared to forest (Raiesi 
and Beheshti, 2014; Acosta-Martínez et al., 2014; Medeiros et al., 2015). Yé et al. (2017) studied soil chemical and biological characteristics of a perennially and annually grazed Sudanian savanna and showed that perennial grasses have a greater influence on soil attributes than annuals.

It is therefore not surprising that annual cropping species require more management and result in higher soil disturbance when compared to perennial crops with less soil disturbance, which reduces the need for fertilizers, pesticides, and irrigation (Fazio and Barbanti, 2014). However, there is a gap in understanding how annual and perennial crops reflect the changes in absolute and specific enzyme activity in sandy soils, mainly in tropical dry areas. Our objective was to determine the changes in soil chemical, organic $\mathrm{C}$, microbial biomass, and absolute and specific enzyme activity (C, N, P, and S cycle) in Entisols covered with forests and annual and perennial crops in tropical dry areas.

\section{MATERIALS AND METHODS}

\section{Description of the study area, climate conditions, and soil samples}

Soil samples were collected from perennial and annual crops and a young secondary forest (control) in the Brazilian semiarid region (Figure 1). In each land use area, four $100 \mathrm{~m}^{2}$ areas were delimited and soil was collected at the $0-10$ $\mathrm{cm}$ layer. The selected areas had similar topographies, altitudes, and climates. The climate is hot and humid (As) according to the Köppen classification system. Annual rainfall was approximately $782 \mathrm{~mm}$ and soils were classified as sandy Entisols.

Soil samples were collected during the dry season. The selected perennial areas were TOM = Solanum lycopersicum L. (monoculture with periodic addition of chemical fertilizers and other inputs, such as chemicals to control weeds and diseases, under drip irrigation management), PASTURE = Digitaria eriantha Steud. (pangola grass monoculture), $\mathrm{COT}=$ Gossypium hirsutum L. (monoculture located next to the highway with weeding),

Figure 1. Schematic map showing study area locations.

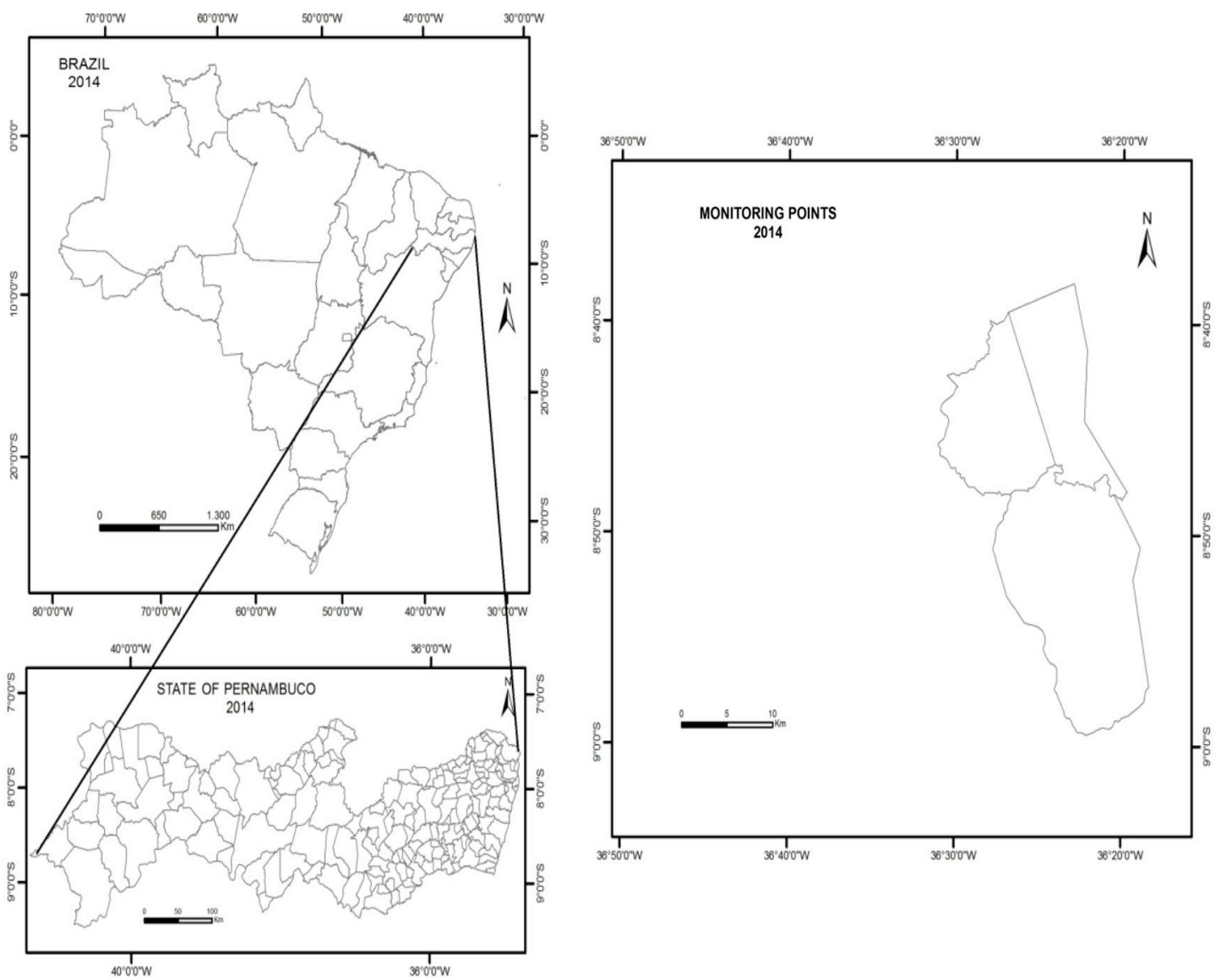


CASHEW = Anacardium occidentale L. (monoculture with 15-yr old trees), and PASSION = Passiflora edulis Sims f. flavicarpa O. Deg. (monoculture with drip irrigation in stony soil that is difficult to excavate).

The areas considered as annual crops were $\mathrm{BEAN}=$ Phaseolus vulgaris $\mathrm{L}$. (common bean monoculture fertilized with cow manure when preparing the growing area and with no irrigation management), CABBAGE $=$ Brassica oleracea L. (monoculture under a traditional cultivation system with added chemical fertilizers and inputs for pest and disease control, PIGPEA = Cajanus cajan (L.) Huth (pigeon pea monoculture with no pesticide use, no irrigation, and exhibiting organic material accumulation at the base of the plants), and FEN = Pimpinella anisum L. (fennel monoculture on a stony slope). More information can be found in Barros et al. (2014).

\section{Chemical attributes, soil organic C (SOC), and microbial biomass C (MBC)}

The determined chemical attributes were water $\mathrm{pH}(1: 2.5)$, available $\mathrm{P}$, and exchangeable $\mathrm{K}, \mathrm{Al}, \mathrm{Ca}$, and $\mathrm{Mg}$. Exchangeable $\mathrm{P}$ and $\mathrm{K}$ were extracted by Mehlich-1, and $\mathrm{K}$ was quantified using flame photometry after extraction. Extractable inorganic $\mathrm{P}$ was quantified by colorimetry (Table 1).

Table 1. Chemical attributes of Entisols covered with forests and annual and perennial crops in Brazilian tropical dry areas.

\begin{tabular}{|c|c|c|c|c|c|c|c|}
\hline Code & $\mathrm{pH}$ & $P$ & $\mathrm{~K}$ & $\mathrm{Ca}$ & $\mathrm{Mg}$ & $\mathrm{Al}$ & $\mathrm{Al}+\mathrm{H}$ \\
\hline & & $\mathrm{mg} \mathrm{kg}^{-1}$ & & - & $\mathrm{cmol}_{\mathrm{c}} \mathrm{kg}^{-1}$ & & \\
\hline FOR & 5.76 & 01.60 & 0.02 & 07.50 & 0.95 & 0.10 & 2.37 \\
\hline TOM & 7.32 & 381.60 & 0.03 & 27.00 & 3.25 & 0.06 & 1.21 \\
\hline PASTURE & 5.53 & 00.20 & 0.02 & 05.00 & 0.85 & 0.07 & 2.09 \\
\hline COT & 5.48 & 01.20 & 0.02 & 06.6 & 1.25 & 0.08 & 2.09 \\
\hline PASSION & 5.79 & 22.18 & 0.02 & 12.50 & 1.33 & 0.07 & 2.09 \\
\hline CASHEW & 6.36 & 15.86 & 0.02 & 04.00 & 0.95 & 0.08 & 1.60 \\
\hline BEANS & 6.08 & 02.53 & 0.02 & 03.50 & 0.93 & 0.07 & 1.21 \\
\hline CABBAGE & 6.97 & 239.61 & 0.04 & 19.50 & 2.20 & 0.08 & 1.21 \\
\hline PIG PEA & 5.20 & 13.30 & 0.03 & 12.50 & 0.75 & 0.05 & 1.71 \\
\hline FEN & 6.77 & 02.24 & 0.02 & 12.00 & 1.60 & 0.10 & 1.27 \\
\hline
\end{tabular}

FOR: Forest; TOM: Solanum lycopersicum; PASTURE: Digitaria eriantha; COT: Gossypium hirsutum; PASSION: Passiflora edulis f. flavicarpa; CASHEW: Anacardium occidentale; BEAN: Phaseolus vulgaris; CABBAGE: Brassica oleracea; PIGPEA: Cajanus cajan; FEN: Pimpinella anisum.

The SOC content was analyzed according to work by Yeomans and Bremner (1988). The MBC soil content was determined by the irradiation method (Mendonca and Matos, 2005). The MBC was determined using $0.5 \mathrm{M} \mathrm{K}_{2} \mathrm{SO}_{4}$ as the extractant, and $80 \mathrm{~mL}$ extractant was added to $20 \mathrm{~g}$ of soil for each sample. The $\mathrm{C}$ content in the extracts was determined by the colorimetric method (Bartlett and Ross, 1988).

\section{Absolute enzyme activity}

Enzyme activity was estimated based on the colorimetric analysis of products released by each enzyme. This occurred when the soil sample was subjected to standard incubation conditions with adequate substrate (Sigma-Aldrich, St. Louis, Missouri, USA) and measured with a spectrophotometer (Libra S22, Biochrom, Cambridge, UK).

Overall enzyme activity was estimated by fluorescein diacetate (FDA) hydrolysis according to Chen et al. (1988) and 3-6-diacetyl fluorescein as substrate. We measured the absolute enzyme activity of $\beta$-glucosidase (Beta) (3.2.1.21) according to a study by Eivazi and Tabatabai (1988) using $p$-nitrophenyl- $\beta$-D-glucoside as substrate; dehydrogenase (Dehy) (1.1.1) was measured based on Casida Jr. et al. (1964) using 2,3,5-triphenyltetrazolium chloride as substrate. Urease (URE) (EC 3.5.1.5), the enzyme involved in the N cycle, was estimated according to the methodology by Kandeler and Gerber (1988) using urea as substrate. Arylsulfatase (ARY) (EC 3.1.6.1), the enzyme involved in the S cycle, was estimated according to the method by Tabatabai and Bremmer (1972); enzymes involved in the $\mathrm{P}$ cycle, acid (P ac), and alkaline phosphatases (P alk) (EC 3.1.3) were estimated according to Eivazi and Tabatabai (1977) with $p$-nitrophenyl phosphate. 


\section{Specific enzymatic activity per unit of SOC and MBC}

To determine the specific enzyme activity per unit of SOC, each absolute enzyme activity was divided by SOC (Acosta-Martínez et al., 2014). To determine the specific enzyme activity per unit of MBC, the enzymatic activity was divided by MBC according to previous methods (Medeiros et al., 2015).

\section{Data analysis}

Data were subjected to ANOVA and contrast comparisons were calculated by Scott-Knott adjustments. To determine which biochemical attributes can be used as quality indicators, data were subjected to principal component analysis (PCA) with 5\% significance. To obtain the eigenvalues and eigenvectors, we used Pearson's correlation matrix to create similarity (Mota et al., 2014).

\section{RESULTS AND DISCUSSION}

The SOC significantly differed $(\mathrm{P}<0.05)$ between all annual and perennial areas compared to FOR (Figure $2 \mathrm{~A}$ ). Forest soils generally have the best quality due to the development of climax vegetation and because we used these soils to compare them with annual and perennial crops. There is a vast literature about SOC decreasing land use as compared to forests (Wang et al., 2012), including Brazilian semiarid regions (Medeiros et al., 2015; Chazdon et al., 2016).

Thus, SOC content in the present study was lower than in forests from India (Pandey et al., 2014) and Iran (Raiesi and Beheshti, 2014) because we used a young secondary dry forest, the Caatinga, which is an exclusive biome in Brazil. The secondary forest in the Brazilian semiarid region has peculiar features, such as the distinctive phenological patterns of plant growth and litter decomposition, due to climate seasonality, which leads to C losses with soil respiration (Ribeiro et al., 2016). In addition, the Brazilian dry forest showed low vegetation biomass that mainly consists of annual species that dry and disappear during the dry season (Moura et al., 2016).

However, the lowest SOC content in PASSION soils occurred because the soil is stony and has few litter inputs. These inputs are quickly decomposed by microbial transformations that release essential nutrients and modify physicochemical properties (Beheshti et al., 2012), which can alter soil microbial and biochemical properties (Raiesi and Beheshti, 2014). Scarce inputs therefore substantially changed the organic matter of PASSION soils.

The sandy Entisols cultivated with annual crops did not follow the same model as perennial crops for MBC (Figure 2B). Management showed more influence in MBC than the effect of annual or perennial crops. For example, CABBAGE and TOM exhibited the highest MBC due to the agrochemical inputs that can stimulate microbial populations because of the microorganisms used as substrates (Medeiros et al., 2014).

Sandy Entisols covered with FOR and perennial and annual crops from tropical dry areas showed high differences in FDA $(\mathrm{P}<0.05)$ (Figure 3A). The highest rates were detected in TOM and FOR. The TOM soils received agrochemicals that potentially increased the microbial community population, which was found in MBC. This variable is important to understand the global enzyme activity of the analyzed soil (Jiang et al., 2016).

Figure 2. Soil organic carbon (SOC) and microbial biomass carbon (MBC) of the Entisols covered with forests and annual and perennial crops in Brazilian tropical dry areas.
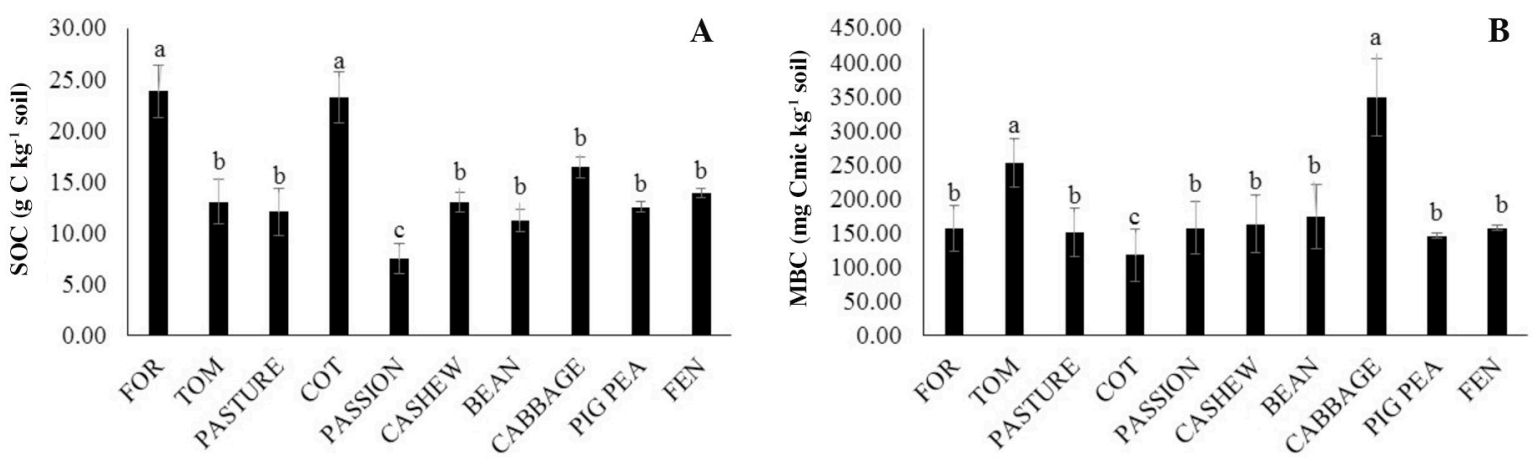

FOR: Forest; TOM: Solanum lycopersicum; PASTURE: Digitaria eriantha; COT: Gossypium hirsutum; PASSION: Passiflora edulis; CASHEW: Anacardium occidentale; BEAN: Phaseolus vulgaris; CABBAGE: Brassica oleracea; PIGPEA: Cajanus cajan; FEN: Pimpinella anisum.

The same letters indicate nonsignificant differences according to Scott-Knott at $P<0.05$. 
Figure 3. Absolute enzyme activity of Entisols covered with forests and annual and perennial crops in Brazilian tropical dry areas. A) Fluorescein diacetate hydrolysis, B) dehydrogenase, C) $\beta$-glucosidase, D) urease, E) arylsulfatase, and F) acid and alkaline phosphatases.
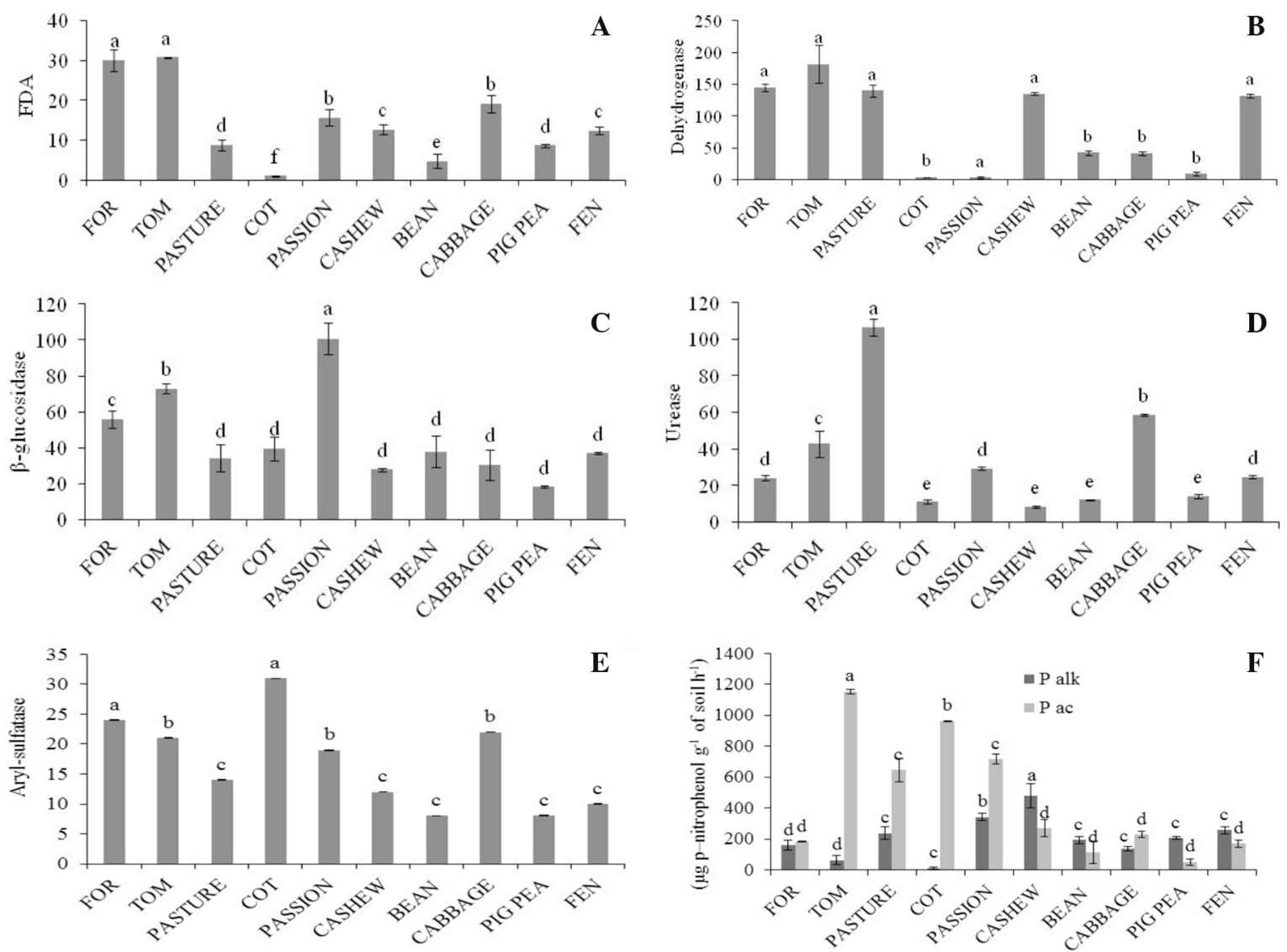

FOR: Forest; TOM: Solanum lycopersicum; PASTURE: Digitaria eriantha; COT: Gossypium hirsutum; PASSION: Passiflora edulis; CASHEW: Anacardium occidentale; BEAN: Phaseolus vulgaris; CABBAGE: Brassica oleracea; PIGPEA: Cajanus cajan; FEN: Pimpinella anisum; FDA: fluorescein diacetate hydrolysis ( $\mu$ g hydrolysates $\mathrm{g}^{-1}$ soil); dehydrogenase ( $\mu \mathrm{L} \mathrm{H} \mathrm{g} \mathrm{H}^{-1}$ soil); $\beta$-glucosidase ( $\mu \mathrm{g} p$-nitrophenol g $\mathrm{g}^{-1}$ soil $\mathrm{h}^{-1}$ ); urease $\left(\mu \mathrm{g} \mathrm{NH} \mathrm{NH}_{4}-\mathrm{N}^{-1}\right.$ dry soil $\left.\mathrm{h}^{-1}\right)$; arylsulfatase $\left(\mu \mathrm{g}\right.$-nitrophenol $\mathrm{g}^{-1}$ soil $\left.\mathrm{h}^{-1}\right) ; \mathrm{P}$ ac: acid phosphatases; $\mathrm{P}$ alk: alkaline phosphatase.

The same letters indicate nonsignificant differences according to Scott-Knott at $P<0.05$.

Enzyme values are expressed as mean $\pm \mathrm{SE}$.

Perennial crops strongly influenced dehydrogenase activity (Figure 3B). The FOR, TOM, and PASTURE resulted in increased DEHY when compared to annual crops, with the exception of FEN. The DEHY activity values were lower in the other soils, and losses were up to $97 \%$ compared to FOR soils. The PASSION soils were stony, with low coverage, and sun-exposed, this potentially resulted in stress as the temperature increased and low moisture was retained. These soils would therefore support microorganisms that maintain high organic matter oxidation levels. This enzyme activity quantifies the respiratory activity of soils associated with the metabolic activity of microorganisms (Medeiros et al., 2015); it demonstrates a positive change in TOM soil because it had a higher MBC content. Extracellular enzymes present in the soil are very important for organic matter decomposition and biogeochemical cycles. The dehydrogenase enzyme is linked to cells and catalyzes the oxidation of organic compounds by removing electrons from the hydrogen that will be captured by the coenzymes.

The TOM soil had the second highest Beta activity related to the $\mathrm{C}$ cycle; this was probably due to $\mathrm{C}$ inputs in TOM areas (Figure 3C). Soils with annual PIGPEA crops had the lowest Beta activity. Lebrun et al. (2012) verified that plant residue rates were between 1.15 and $0.61 \mu \mathrm{mol} \mathrm{PNP} \mathrm{h}^{-1} \mathrm{~g}^{-1}$ in a Luvisols subjected to a grazing system in the Yvetot area in northern France. This enzyme controls the release of glucose, which is a major source of energy for microorganisms. 
All sandy Entisols covered with perennial and annual crops had urease activity, but with different values (Figure 3D). This difference was greater than the urease activity values in soils in China (Xiu-Mei et al., 2008). The URE is involved in the $\mathrm{N}$ cycle; it is sensitive to fertilization and can be inhibited in the presence of high $\mathrm{N}$ contents. The urease concentration varies with land use, as shown in soils in China (Wang et al., 2012).

Overall, soils with perennial crops showed higher ARY, P ac, and P alk values when compared to annual crops (Figures $3 \mathrm{E}$ and $3 \mathrm{~F}$ ) because perennial crops have less soil disturbance. In the present study, we observed low arylsulfatase activity in the Entisol covered with annual and perennial crops (Figure 3E). Raiesi and Beheshti (2014) evaluated the arylsulfatase activity of forest and paddy rice soils and observed higher values than the activity observed in our study; this was probably because the activity of this enzyme is influenced by soil properties and management system (Acosta-Martínez et al., 2008), which is consistent with perennial and annual areas in the present study.

When individual enzymes are analyzed, enzyme activity can result in errors due to interactions with other soil factors. To resolve this, several studies have recommended using specific enzyme activity per unit of SOC and MBC (Raiesi and Beheshti, 2014; Medeiros et al., 2017) because the specific enzymatic activity per unit of SOC expresses the nutritional status of organic matter from the perspective of the microorganism (Wang et al., 2012).

The specific FDA per unit of SOC was generally higher in perennial crops (Table 2) when compared to annual crops because soils disturbed by human activities have enzymatic activity per unit of SOC higher than forest soils (Trasar-Cepeda et al., 2008); this is probably due to decreases in the most labile and less stabilized organic matter. This result was also observed by Medeiros et al. (2015), who evaluated the specific enzymes per unit of SOC in sandy soil with monoculture and intercropping and observed that some specific activity was higher in soils with crops than in the forest. Raiesi and Beheshti (2014) evaluated the activity of urease, alkaline phosphatase, acid phosphatase, and invertase arylsulfatase per unit of SOC in rice paddy soils and forest in northwest Iran, and they observed that the highest specific activity was found in croplands.

Table 2. Specific enzyme activity per unit of soil organic carbon (SOC) and microbial biomass carbon (MBC) in Entisols covered with forests and annual and perennial crops in Brazilian tropical dry areas.

\begin{tabular}{|c|c|c|c|c|c|c|c|}
\hline & \multicolumn{7}{|c|}{ Specific enzyme activity per unit of SOC } \\
\hline & FDA & Dehy & Beta & Ure & Ary & P alk & $\mathrm{Pac}$ \\
\hline FOR & 5.76 & 01.60 & 0.02 & 07.50 & 0.95 & 0.10 & 2.37 \\
\hline TOM & 7.32 & 381.60 & 0.03 & 27.00 & 3.25 & 0.06 & 1.21 \\
\hline PASTURE & 5.53 & 00.20 & 0.02 & 05.00 & 0.85 & 0.07 & 2.09 \\
\hline COT & 5.48 & 01.20 & 0.02 & 06.6 & 1.25 & 0.08 & 2.09 \\
\hline PASSION & 5.79 & 22.18 & 0.02 & 12.50 & 1.33 & 0.07 & 2.09 \\
\hline CASHEW & 6.36 & 15.86 & 0.02 & 04.00 & 0.95 & 0.08 & 1.60 \\
\hline BEANS & 6.08 & 02.53 & 0.02 & 03.50 & 0.93 & 0.07 & 1.21 \\
\hline CABBAGE & 6.97 & 239.61 & 0.04 & 19.50 & 2.20 & 0.08 & 1.21 \\
\hline PIG PEA & 5.20 & 13.30 & 0.03 & 12.50 & 0.75 & 0.05 & 1.71 \\
\hline \multirow[t]{3}{*}{ FEN } & 6.77 & 02.24 & 0.02 & 12.00 & 1.60 & 0.10 & 1.27 \\
\hline & \multicolumn{7}{|c|}{ Specific enzyme activity per Unit of MBC } \\
\hline & FDA & Dehy & Beta & Ure & Ary & $\mathrm{P}$ alk & $\mathrm{Pac}$ \\
\hline FOR & $0.19 \mathrm{a}$ & $0.93 a$ & $0.36 \mathrm{~b}$ & $0.15 b$ & $0.15 b$ & $1.02 \mathrm{~b}$ & $1.16 \mathrm{~d}$ \\
\hline TOM & $0.12 b$ & $0.72 b$ & $0.29 \mathrm{c}$ & $0.17 \mathrm{~b}$ & $0.08 \mathrm{~b}$ & $0.25 \mathrm{c}$ & $4.56 \mathrm{~b}$ \\
\hline PASTURE & $0.06 \mathrm{~b}$ & $0.92 b$ & $0.23 \mathrm{c}$ & $0.70 \mathrm{a}$ & $0.09 \mathrm{~b}$ & $1.57 \mathrm{~b}$ & $4.26 \mathrm{c}$ \\
\hline COT & $0.01 \mathrm{~b}$ & $0.04 \mathrm{c}$ & $0.34 \mathrm{~b}$ & $0.09 \mathrm{c}$ & $0.26 \mathrm{a}$ & $0.09 \mathrm{c}$ & $8.15 \mathrm{a}$ \\
\hline PASSION & $0.10 \mathrm{~b}$ & $0.02 \mathrm{c}$ & $0.64 \mathrm{a}$ & $0.19 b$ & $0.12 b$ & $2.17 \mathrm{a}$ & $4.55 \mathrm{c}$ \\
\hline CASHEW & $0.08 b$ & $0.83 b$ & $0.17 \mathrm{c}$ & $0.05 \mathrm{~d}$ & $0.07 \mathrm{~b}$ & $2.95 \mathrm{a}$ & $1.66 \mathrm{~d}$ \\
\hline BEANS & $0.03 \mathrm{~b}$ & $0.24 \mathrm{c}$ & $0.22 \mathrm{c}$ & $0.07 \mathrm{~d}$ & $0.04 \mathrm{~b}$ & $1.10 \mathrm{~b}$ & $0.64 \mathrm{~d}$ \\
\hline CABBAGE & $0.06 \mathrm{~b}$ & $0.12 \mathrm{c}$ & $0.09 \mathrm{c}$ & $0.17 \mathrm{~b}$ & $0.06 \mathrm{~b}$ & $0.39 \mathrm{c}$ & $0.66 \mathrm{~d}$ \\
\hline PIG PEA & $0.06 \mathrm{~b}$ & $0.06 \mathrm{c}$ & $0.13 \mathrm{c}$ & $0.10 \mathrm{c}$ & $0.05 b$ & $1.41 \mathrm{~b}$ & $0.35 \mathrm{~d}$ \\
\hline FEN & $0.08 b$ & $0.84 b$ & $0.24 \mathrm{c}$ & $0.16 \mathrm{~b}$ & $0.08 \mathrm{~b}$ & $1.63 \mathrm{~b}$ & $1.07 \mathrm{~d}$ \\
\hline
\end{tabular}

FOR: Forest; TOM: Solanum lycopersicum; PASTURE: Digitaria eriantha; COT: Gossypium hirsutum; PASSION: Passiflora edulis; CASHEW: Anacardium occidentale; BEAN: Phaseolus vulgaris; CABBAGE: Brassica oleracea; PIGPEA: Cajanus cajan; FEN: Pimpinella anisum; FDA: fluorescein diacetate hydrolysis; Dehy: dehydrogenase; Beta: $\beta$-glucosidase; Ure: urease; Ary: arylsulfatase; P alk: alkaline phosphatase; P ac: acid phosphatase.

The same letters indicates nonsignificant differences according to Scott-Knott at $P<0.05$. Enzyme values are expressed as mean \pm SE. 
Soils with the perennial PASSION crop had a specific activity per unit of SOC that was usually greater, with the exception of Dehy and URE (Table 2), demonstrating an ecological imbalance. The PASSION crops were in stony soils and had less organic matter compared to the forest. This high specific enzymatic activity per unit of SOC is an ecological mechanism to retain metabolic activity that is at risk due to the loss of organic matter.

Sandy Entisols from tropical dry forests had higher FDA and Dehyd specific enzyme activity per unit of MBC compared to soils cultivated with annual and perennial crops, which indicated that forest soils contained microorganisms that are metabolically more active (Lagomarsino et al., 2011). Specific activity per unit of MBC shows that enzymatic activity was produced by microorganisms because enzyme activity could be produced by animals, plants, and microorganisms (Acosta-Martínez et al., 2014). This specific activity is an important indicator that provides ecological information (Lagomarsino et al., 2011) and has been used in recent studies. Specific activity per unit of SOC or MBC clearly indicated changes in soil absolute enzymatic activity (Raiesi and Beheshti, 2014; Medeiros et al., 2015).

Multivariate PCA was used to select the variables that were mainly responsible for detecting differences in soil quality of forests and annual and perennial crops according to the description by Pandey et al. (2014). This method was previously used in studies of microbial (Acosta-Martínez et al., 2010; Notaro et al., 2014), physical (Mota et al., 2014), and biochemical (Medeiros et al., 2015) parameters and soil organic C contents in forests. Based on the relationships between the evaluated attributes, two-dimensional diagrams were constructed to visually evaluate vectors. The first two factors showed a cumulative percentage of $79.01 \%$ (Figure 4A). According to the vector projection diagram, principal component 1 , with the most influential factors, was responsible for $59.79 \%$ of the total variation with Beta $=\mathrm{ARY}>\mathrm{P}$ ac $/ \mathrm{SOC}>\mathrm{Beta} / \mathrm{SOC}>\mathrm{Pac}>\mathrm{FDA} / \mathrm{SOC}>\mathrm{Beta} / \mathrm{MBC}$. Principal component 2 accounted for $19.22 \%$ of the total variation with $\mathrm{P}$ ac/MBC $>$ Ary (Figure 4A). This result demonstrated the importance of specific enzyme activity per unit of SOC and MBC related to absolute activity because it was more sensitive to detect differences in all treatments than absolute enzyme activity in PCA analysis. Specific enzyme activity per unit of SOC and MBC was also used by Pandey et al. (2014) to evaluate the differences between conventional tillage and no-tillage systems in rice cultivation. Medeiros et al. (2015) demonstrated the importance of these variables to detect changes in soils that were cultivated with intercropping and monoculture in sandy soils from tropical dry areas.

Figure 4. A) Diagram of vector projection and B) dispersion of biochemical indicators of Entisols covered with forests and annual and perennial crops in Brazilian tropical dry areas.
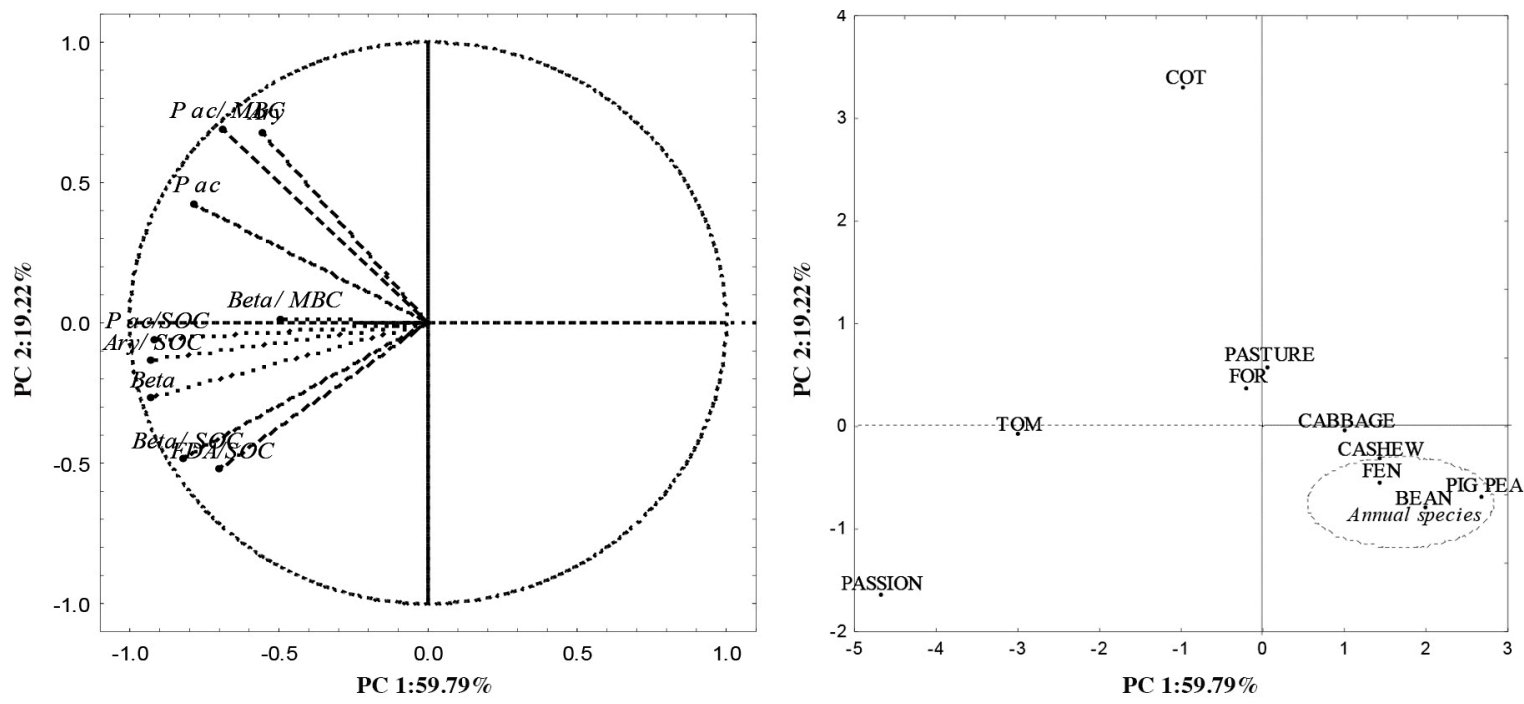

FOR: Forest; TOM: Solanum lycopersicum; PASTURE: Digitaria eriantha; COT: Gossypium hirsutum; PASSION: Passiflora edulis; CASHEW: Anacardium occidentale; BEAN: Phaseolus vulgaris; CABBAGE: Brassica oleracea; PIGPEA: Cajanus cajan; FEN: Pimpinella anisum; Beta: $\beta$-glucosidase; Ary: arylsulfatase; FDA/SOC: fluorescein diacetate hydrolysis/soil organic C; Beta/SOC: $\beta$-glucosidase/soil organic C; Ary/SOC: arylsulfatase/soil organic $\mathrm{C}$; $\mathrm{P}$ ac/SOC: acid phosphatase/soil organic $\mathrm{C}$; Beta/MBC: $\beta$-glucosidase/microbial biomass $\mathrm{C}$; $\mathrm{P}$ ac/MBC: acid phosphatase/microbial biomass $\mathrm{C}$. 
Valarini et al. (2007) observed that organic tomato cultivation provided the highest soil microbial diversity, which resulted in greater nutrient availability and improved soil structure and fertility compared to conventional farming systems. This finding corresponds to data obtained in the present study, which showed that less intensive cultivation systems had a lower impact resulting from biochemical soil attribute management. According to the same author, PCA allows determining the changes that occur in the soil as a function of more reliable management.

The multivariate PCA was important because the Entisols covered with annual crops were grouped in the same quadrant (Figure 4B). These soils are far from FOR soils, which indicate an ecological imbalance in the soils receiving more intensive management practices (such as annual crops). This result corresponds to findings by Medeiros et al. (2015), who showed that soils with less intensive management and intercropping showed a balance that was similar to that of the forest soils.

Using these indicators proved that the conversion of forest into pasture could not cause any drastic changes in the quality of Entisols depending on how the area is managed because these two soils are very close in the dispersion diagram (Figure 3B). Thus, the selected variables can be used as indicators of Entisol quality when Entisols are cultivated with perennial and annual crops in tropical dry areas.

\section{CONCLUSIONS}

We demonstrated that the enzymatic activity (C, N, S, and P cycle), microbial biomass, soil organic carbon (SOC), and the chemical attributes of Entisols from tropical dry areas are affected differently when covered with perennial or annual crops. The multivariate PCA analysis grouped the Entisols with annual crops as being distant from forest soils. This study demonstrated that absolute $\beta$-glucosidase, arylsulfatase, and alkaline phosphatase activity, and the specific fluorescein diacetate hydrolysis/SOC, $\beta$-glucosidase/SOC, arylsulfatase/SOC, acid phosphatase/SOC, $\beta$-glucosidase/MBC, and acid phosphatase/MBC indicators are sensitive for detecting changes in Entisol quality; it is possible to detect pasture soil quality similar to that of forest soil quality when pastures are managed appropriately in tropical dry areas.

\section{ACKNOWLEDGEMENTS}

The authors thank Conselho Nacional de Desenvolvimento Científico e Tecnológico (CNPq) for financial support (Process 481436/2010-3 and 562584/2010-2), a postdoctoral scholarship abroad was received by the corresponding author (249051/2013-3), and FACEPE for financial support (APQ-1077-5.01/10).

\section{REFERENCES}

Acosta-Martínez, V., Acosta-Mercado, D., Sotomayor-Ramíres, D., and Cruz-Rodrígues, L. 2008. Microbial communities and enzymatic activities under different management in semiarid soil. Applied Soil Ecology 38:249-260. doi:10.1016/j. apsoil.2007.10.012.

Acosta-Martínez, V., Bell, C.W., Morris, B.E.L., Zak, J., and Allen, V.G. 2010. Long-term soil microbial community and enzyme activity responses to an integrated cropping-livestock system in a semi-arid region. Agriculture, Ecosystems and Environment 37:231-240. doi:10.1016/j.agee.2010.02.008.

Acosta-Martínez, V., Moore-Kucerab, J., Cotton, J., Gardnera, T., and Westerd, D. 2014. Soil enzyme activities during the 2011 Texas record drought/heatwave and implications to biogeochemical cycling and organic matter dynamics. Applied Soil Ecology 75:43-51. doi:10.1016/j.apsoil.2013.10.008.

Barros, J.A., Medeiros, E.V., Notaro, K.A., Moraes, W.S., Silva, T.C.E.S., and Moreira, K.A. 2014. Different cover promote sandy soil suppressiveness to root rot disease of cassava caused by Fusarium solani. African Journal of Microbiology Research 8:967-973. doi:10.5897/AJMR2014.6607.

Bartlett, R.J., and Ross, D.S. 1988. Colorimetric determination of oxidizable carbon in acid soil solutions. Soil Science Society of America 52:191-1192. doi:10.2136/sssaj1988.03615995005200040055x.

Beheshti, A., Raiesi, F., and Golchin, A. 2012. Soil properties, C fractions and their dynamics in land use conversion from native forests to croplands in northern Iran. Agriculture, Ecosystems and Environment 148:121-133. doi:10.1016/j. agee.2011.12.001. 
Casida Jr.,L.E.,Klein,D.A., and Santoro,T. 1964 . Soil dehydrogenase activity. Soil Science 98:371-376.doi:10.5772/48294.

Chazdon, R.L., Broadbent, E.N., Rozendaal, D.M., Bongers, F., Zambrano, A.M.A., Aide, T.M., et al. 2016. Carbon sequestration potential of second-growth forest regeneration in the Latin American tropics. Science Advances 2(5):e1501639. doi:10.1126/sciadv.1501639. http://dx.doi.org/.

Chen, W., Hoitinik, A.J., Schmitthenner, A.F., and Touvinen, O.H. 1988. The role of microbial activity in suppression of damping-off caused by Pythium ultimum. Phytophatology 78:314-322. doi:10.1094/Phyto-78-314.

Eivazi, F., and Tabatabai, M.A. 1977. Phosphatases in soils. Soil Biology and Biochemistry 9:167-172. doi:10.1016/00380717(77)90070-0.

Eivazi, F., and Tabatabai, M.A. 1988. Glucosidases and galactosidases in soils. Soil Biology and Biochemistry 20:601606. doi:10.1016/0038-0717(88)90141-1.

Fazio, S., and Barbanti, L. 2014. Energy and economic assessments of bio-energy systems based on annual and perennial crops for temperate and tropical areas. Renewable Energy 69:233-241. doi:10.1016/j.renene.2014.03.045.

Jiang, S., Huang, J., Lu, H., Liu, J., and Yan, C. 2016. Optimisation for assay of fluorescein diacetate hydrolytic activity as a sensitive tool to evaluate impacts of pollutants and nutrients on microbial activity in coastal sediments. Marine Pollution Bulletin 110(1):424-431. doi:10.1016/j.marpolbul.2016.06.031.

Kandeler, E., and Gerber, H. 1988. Short-term assay of soil urease activity using colorimetric determination of ammonium. Biology and Fertility of Soils 6:68-72. doi:10.1007/BF00257924.

Lagomarsino, A., Benedetti, A., Marinari, S., Pompili, L., Moscatelli, M.C., Roggero, P.P., et al. 2011. Soil organic C variability and microbial functions in a Mediterranean agro-forest ecosystem. Biology and Fertility of Soils 47:283291. doi:10.1007/s00374-010-0530-4.

Lebrun, J.D., Trisoutrot-Gattin, I., Vinceskas-Akpa, Bailleul, C., Brault, A., Mougin, M., et al. 2012. Assessing impacts of copper soil enzyme activities in regard to their natural spatiotemporal variation under long-term different land uses. Soil Biology and Biochemistry 40:150-156. doi:10.1016/j.soilbio.2012.02.027.

Medeiros, E.V., Duda, G.P., dos Santos, L.A.R., de Sousa Lima, J.R., de Almeida-Cortêz, J.S., Hammecker, C., et al. 2017. Soil organic carbon, microbial biomass and enzyme activities responses to natural regeneration in a tropical dry region in Northeast Brazil. Catena 151:137-146. doi:10.1016/j.catena.2016.12.012.

Medeiros, E.V., Notaro, K.A., Barros, J.A., Moraes, W.S., Silva, A.S., and Moreira, K.A. 2015. Absolute and specific enzymatic activities of sandy Entisol from tropical dry forest, monoculture and intercropping areas. Soil and Tillage Research 145:208-215. doi:10.1016/j.still.2014.09.013.

Medeiros, E.V., Notaro, K.A., Bezerra, C.B., Andrade, A.R., and Duda, G.P. 2014. Impact of glyphosate on microbial attributes of soil planted with two species of passion fruit. Revista Caatinga 2:1-8.

Mendonca, E.S., e Matos, E.S. 2005. Matéria orgânica do solo: Métodos de análises. p. 86-92. Universidade Federal de Viçosa (UFV), Viçosa, Brasil.

Mota, J.C.A., Alves, C.V.O., Freire, A.G., and Assis Júnior, R.N. 2014. Uni and multivariate analyses of soil physical quality indicators of a Cambisol from Apodi Plateau-CE, Brazil. Soil and Tillage Research 140:66-73. doi:10.1016/j. still.2014.02.004.

Moura, P.M., Althoff, T.D., Oliveira, R.A., Souto, J.S., Souto, P.C., Menezes, R.S., et al. 2016. Carbon and nutrient fluxes through litter fall at four succession stages of Caatinga dry forest in Northeastern Brazil. Nutrient Cycling in Agroecosystems 105(1):25-38. doi:10.1007/s10705-016-9771-4.

Notaro, K.A., Medeiros, E.V., Duda, G.P., Silva, A.O., and Moura, P.M. 2014. Agroforestry systems, nutrients in litter and microbial activity in soils cultivated with coffee at high altitude. Scientia Agricola 71:87-95. doi:10.1590/S010390162014000200001.

Pandey, D., Agrawal, M., and Bohra, J.S. 2014. Effects of conventional tillage and no tillage permutations on extracellular soil enzyme activities and microbial biomass under rice cultivation. Soil and Tillage Research 136:51-60. doi:10.1016/j. still.2013.09.013.

Quesada, M., Sanchez-Azofeifa, G.A., Alvarez-Anorve, M., Stoner, K.E., Avila-Cabadilla, L., Calvo-Alvarado, J., et al. 2009. Succession and management of tropical dry forests in the Americas: review and new perspectives. Forest Ecology and Management 258(6):1014-1024. doi:10.1016/j.foreco.2009.06.023.

Raiesi,F., and Beheshti, A. 2014. Soil specific enzyme activity shows more clearly soil responses to paddy rice cultivation than absolute enzyme activity in primary forests of northwest Iran. Applied Soil Ecology 75:63-70. doi:10.1016/j. apsoil.2013.10.012.

Ribeiro, K., Sousa-Neto, E.R., Carvalho Junior, J.A., Lima, J.R.S., Menezes, R.S.C., Duarte-Neto, P.J., et al. 2016. Land cover changes and greenhouse gas emissions in two different soil covers in the Brazilian Caatinga. Science of the Total Environment 571:1048-1057. doi:10.1016/j.scitotenv.2016.07.095.

Tabatabai, M.A., and Bremner, J.M. 1972. Distribution of total and available sulfur in selected soils and soil profiles. Agronomy Journal 64:40-44. doi:10.2134/agronj1972.00021962006400010013x.

Trasar-Cepeda, C., Leiros, M.C., and Gil-Stores, F. 2008. Hydrolytic enzyme activities in agricultural and forest soils. Some implications for their use as indicators of soil quality. Soil Biology and Biochemistry 40:2146-2155. doi:10.1016/j. soilbio.2008.03.015. 
Valarini, P.J., Frighetto, R.T.S., Schiavinato, R.J., Campanhola, C., Sena, M.M., Balbino, T.L., et al. 2007. Integrated analysis of production systems of tomato with edaphobiological indicators. Horticultura Brasileira 25:60-67. doi:10.1590/S0102-05362007000100012.

Wang, B., Xue, S., Liu, G.B., Zhang, G.H., Li, G., and Ren, Z.P. 2012. Changes in soil nutrient and enzyme activities under different vegetations in the Loess Plateau area, Northwest China. Catena 92:186-195. doi:10.1016/j.catena.2011.12.004.

Xiu-Mei, L., Qi, L., Wen-Ju, L., and Yong, J. 2008. Distribution of soil enzyme activities and microbial biomass along a latitudinal gradient in farmlands of Songliao Plain, Northeast China. Pedosphere 18:431-440. doi:10.1016/S10020160(08)60034-X.

Yé, L., Lata, J.C., Masse, D., Nacro, H.B., Kissou, R., Diallo, N.H., and Barot, S. 2017. Contrasted effects of annual and perennial grasses on soil chemical and biological characteristics of a grazed Sudanian savanna. Applied Soil Ecology 113:155-165. doi:10.1016/j.apsoil.2017.02.003.

Yeomans, J.C., and Bremner, J.M. 1988. A rapid and precise method for routine determination of organic carbon in soil. Communications in Soil Science and Plant Analysis 19:1467-1476. doi:10.1080/00103628809368027. 